\title{
ピマーイ（イサーン，タイ）の街路体系と街区構成に関する考察 CONSIDERATIONS ON STREET SYSTEM AND FORMATION OF STREET BLOCKS OF PHIMAI (ISAN, THAILAND)
}

\author{
廣富＼cjkstart純*, チャンタニー・チランタナット**, 布野修司*** \\ Jun HIROTOMI, Chantanee CHIRANTHANUT and Shuji FUNO
}

\begin{abstract}
This paper discusses the form of townhouses and traditional houses in northern Thailand, clarifying the process of urban formation and characteristics of living environment. The research this paper is based on tries to compare forms of houses in Thailand with those in other regions of South East Asia and southern China. Our previous papers clarified the typology and its transformation of shop house in Bangkok, Patani and Malacca... In this paper, authors selected Phimai (Isan,Thailand) to consider the formation of urban tissues and its transformation. Phimai (Isan,Thailand) is known as a historic City with many ancient monuments traced back to Angkor Khmer period. One of major focuses of this paper is how the townhouse(shop house) was introduced in Thailand. The paper is composed by historical analysis of the process of establishment and development of Phimai and considerations on block formation and typology of approaches to house lots. Analyzing the characteristics of street system and block, the paper suggests that two types of houses clearly characterizes the spatial formation in Phimai.
\end{abstract}

Keywords: Phimai, Urban Tissue, Shop house, Street System, Formation of Street Block, Khmer City ピマーイ,都市組織,ショップハウス, 街路体系, 街区構成, クメール都市

\section{1 研究の目的と背景}

本稿は,タイ東北部（イサーン）における居住形式および街区組織 に関する研究の一環として,ピマーイの旧市街地の街路体系と街区 構成を明らかにすることを目的としている。

タイ東北部の伝統的住居・集落については, 諸研究注1)によって明 らかにされてきているが, 本稿で注目するのは極めて整然と計画さ れた集落あるいは都市である。中部夕イ, 東北夕イにおける「インド 化」国家の都城については，『曼茶羅都市』(布野修司（2006） ${ }^{4)}$ ) で概観しているが, その中でもピマーイは, 解明す心゙き多くのテーマ を抱えた実に興味深い都市である。ピマーイの中心にあるプラサー ト・ヒン・ピマーイ Prasat Hin Phimai（以降ピマーイ寺院）はア ンコール王朝の最盛期を築いた王を輩出したマヒーダラプラ Mahidarapura 王朝の中心寺院として建設され,アンコールワット, アンコールトムなどの空間構成と直接間接に影響関係があると考え られている。現在のピマーイには建設当初の骨格が残されているが, その都市空間構成を明らかにすることは, 在りし日のアンコール都 城の空間構成を理解寸る一助になると考える。ピマーイの都市その ものについての先行研究はほとんどないが, ピマーイ寺院に関して は比較的多くの文献がある。日本で初めてピマーイに言及したのは 三木栄（1930） ${ }^{16)}$ で, 伊東照司 (1980) ${ }^{12}$ は言語文化研究の視点から ピマーイ寺院の装飾に見られるレリーフの解読を試みている。

本稿で, 主として臨地調査をもとにして明らかにするのは, 現在の ピマーイの都市構成, 特に街路体系と街区構成である。クメールによ
ってヒンドゥー都市の理念に基づいて建設されたピマーイであるが, 当然のことながら, その居住形態は大きく変化してきた。とりわけ, 幹線通りに面して立ち並ぶ店舗併用住宅, いわゆるショップハウス (店屋) 注2) は, 19 世紀中葉以降中国人によって持ち込まれた形式で ある。寺院を中心とした全体の区画割りは大きく変化するところは ないが, 細い街路がつくられ, 街区は分割されてきた。本稿では, 街路 体系, 街路の類型と街区構成の変化について考察したい。

主要な文献は末尾に示寸通りであるが, 現在のピマーイの都市空 間から住居までを総合して論じたのは廣富純（2005）7)がほとんど 唯一のものである注 3$) 。$ 本稿は, そのうち街路体系と街区構成に絞っ てまとめたものである。

臨地調查は, 予備調查を 2003 年 7 月に行い注 4$)$, 本調查 を 2004 年 8 月 2 日から 31 日 まで行った注5) さらに, 本稿を まとめるに当たって, チャン タニー・チランタナットが 2009 年 1 月に補足調查を行っ た。

\section{2 ピマーイの概要}

現在のピマーイは, タイ王 国イサーン州ナコーンラーチ ヤシーマー県ピマーイ郡ナイ

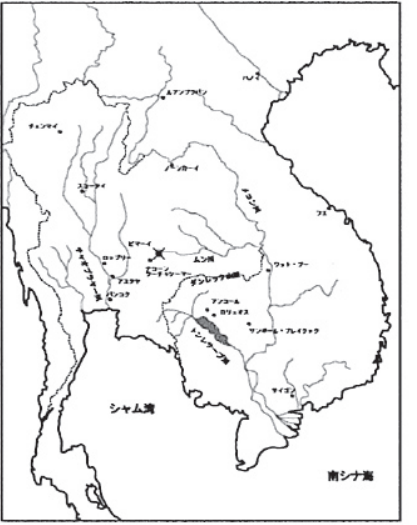

図 1 ピマーイとその周辺
* 佐藤総合計画 工修

** 京都大学大学院 博士後期課程 $\cdot$ 工修

*** 滋賀県立大学大学院環境科学研究科 教授.工博
Graduate School of Architecture, Kyoto University, M. Eng.

$\mathrm{Ph}$. D. Candidate, Graduate School of Architecture, Kyoto University, M. Eng.

Prof., Graduate School of Environmental Science, University of Shiga Prefecture, Dr. Eng. 
ムアン区のピマーイ役場が管轄注6) する。バンコクから北東へおよ そ $300 \mathrm{~km}$ にあるナコーンラーチャシーマーから, さらに北東へ $60 \mathrm{~km}$ 程のところに位置する（図 1 )。2007 年時点でピマーイ郡の人口は 129,897 人である（調査時 121,569 人（2003 年）, その内ピマーイ役 場注7) の管轄区内にはその 1 割弱である 9, 387 人（2008 年：内女性 4, 992 人) が居住しており, ピマーイの城壁内にはその 8 割程度が居 住していると推定される注8)。

コーラート高原を含むイサーンには, 石造建造物群が散在し, 一 帯がかつて扶南, 真臘, アンコールなどクメール文化圈に属していた ことが明らかにされている。カンボジアには真臘時代のイーシャナ ヴァルマン I 世（在 615-635）によると思われる碑文中にビーマプ ラBhimapuraの地名が刻まれており, ピマーイ寺院に残された碑文 にはヴィマーヤプラ Vimayapura という地名がある注9) が, これがピ マーイと考えられている。ヴィマーヤの都市という意味である。ヴ イマーヤという名称は, 仏教の世界観と何らかの関係があるとされ, 伊東照司（1980）は, ピマーイ寺院は密教寺院であり, 11〜12 世紀の インドシナにおける密教寺院の遺構として非常に珍しい例であると いう。一方, ピマーイは, 上座部仏教の卓越した地であったという説 もある。

現在ピマーイを含むコーラート一帯に居住する人々はタイ系民 族の 1 グループであるラオ族の血を引いていると考えられており， およそ 200 年前頃からラオスより移住してきたとされるが, この地 より数多く出土する土器などから, 少なくとも A. D200 年頃から人々 が居住してきたと推察されている。

タイ国鉄コーラート線（バンコクーコーラート）が開通した 1897 年頃よりコーラートへ移住が確認される華人は, 暫くしてピマーイ にもその居住範囲を拡大しており, 現在タイ民族との混血が進んで いる。

アンコール期にコーラート一帯を領地としていたマヒーダラプ ラ王朝の中心として築かれたピマーイ寺院は, アンコール王朝の崩 壊とともにアユタヤ期には既に廃噓と化していたが, アユタヤ朝末 期に 1 度, そして近年では 1964 年〜1969 年にかけてフランス政府の 協力のもと, 寺院の復元が行なわれている。その後も市内に点在する

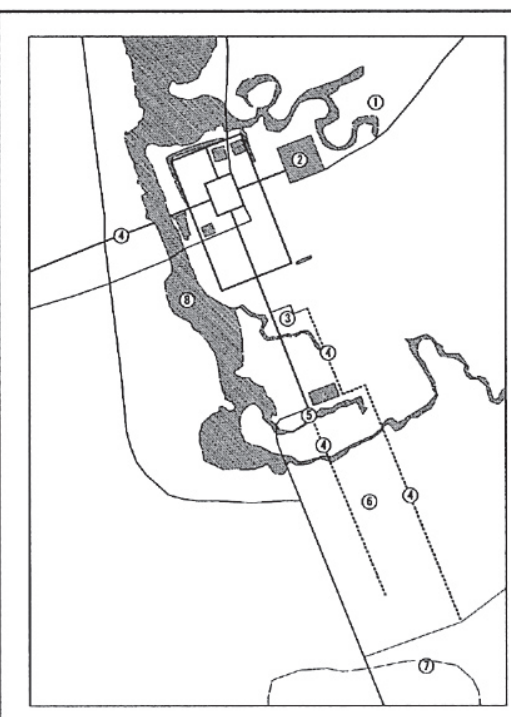

図 2 ピマーイの主要都市要素
遺跡の修復が続き, ピマーイ寺院遺跡コンプレックスは, 国立歴史公 園として指定され, 1989 年 4 月 12 日にシリントーン王女を迎えピマ 一个歴史公園としての開園式が執り行われている注10)。

\section{3 プラサート・ヒン・ピマーイの空間構成}

ピマーイ全体の空間構成を大きく規定しているのがピマーイ寺 院である。1080 年から 1112 年の間に建造されたとされる注11) ピマ 一イ寺院の第一の特徴は, 寺院自体がほぼ南面しており, しかもその 軸線が 20 度程度西に傾いていることである（図 2 )。通常，ヒンドゥ 一寺院は日の出の方角である東を向いて計画される。アンコール都 城の中心寺院は, ほとんど全て東に面して建てられており, ピマーイ 周辺の寺院もその基本に従っている。しかし, ピマーイ寺院の場合, 約 20 度のずれはあるが, 南を向いて建てられている。アンコール地 方を向いているとか, 王道 (アンコールからの幹線道路) の通ってい る方角に合わせたとか諸説あるが, アヌウイット・チャレンスプクン は，「南北軸を世界の基軸」とする「新しい思想に基づく価值体系を 設計に取り入れた」結果であるという注12)。南北軸への転換が何故 行われたのかについてはさらに検討が必要であるが，ピマーイ寺院 は, マヒーダラプラ王朝がアンコール王朝とは異なった独立した権 力であることを象徴するものとして建てられたことは明らかである。 真真南から 20 度程度ずれていることに関しては, 家森俊彦注 13 が 興味深い推論を行っている。この真北からのずれは都城建設時に方 位磁針を用いた結果ではないか, というのである。地磁気は時々刻々 変化しており, その変化は即ち方位磁針の指し示す方角の変化を意 味しているが, 中国西安のある寺院が記録した磁北方向の変動の波 と, タイにおける遺跡の真方角のずれをまとめた波とが非常に似て いるという。コンポン・スヴァイのプリア・カーンがピマーイと同 方向におよそ 20 度, プラサート・ムアン・タムは 10 度, スコータイ も 7 度前後振れている。真の東西南北からずれているものは意外に 多い。日本においても, 少なからぬ寺院の伽藍配置が「磁気方式」に

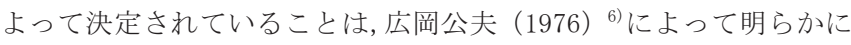
されてい る。
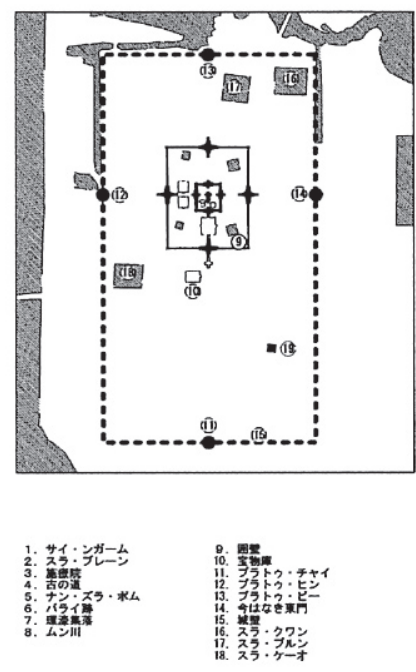

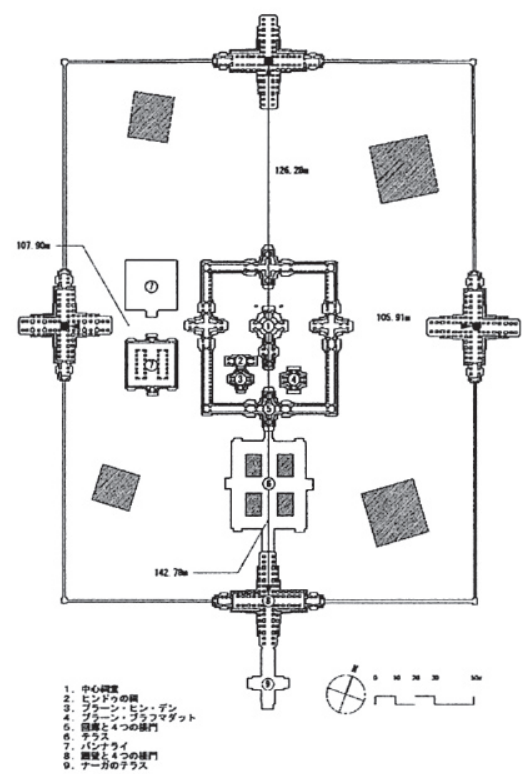

図 3 ピマーイ寺院の主要構成要素 
ピマーイ寺院は, 中心塔堂を回廊と囲壁, そして城壁で 3 重に囲う ように構成されている。さらに城壁の外側には環波が巡り, 非常に堅 固な城として築かれている。また, 城壁の外側には中心祠堂からの東 西副軸上にスラ・プレーンという大きな池がある。城壁は南北に長 い長方形で, 短辺が約 $565 \mathrm{~m}$, 長辺は約 $1030 \mathrm{~m}$ であるが, 現在のピマー イは, 城壁は既になくなり, 環濠も部分的に残るのみである。城壁と 囲壁との間は居住地となっており, 聖域として感じられるのは囲壁 より内側である。ピマーイ寺院の南北主軸に沿って南へ進むと, 城壁 の遥か南に施療院がある。これは, アンコール地方より放射状に伸び る王道に沿って設けられた病院施設であり, ジャヤヴァルマンVII世 注14) 治世下（1181～1220）のものと考えられている。さらに南に歩 を進めるとラムナームケムという河川が交差するが, そこにあるの がナン・スラ・ポム注15) と呼ばれる栈橋である。

ピマーイ寺院は, 城壁も含めてその全てが同時期に造られたわけ ではなく,11 世紀にジャヤヴァルマンVI世（1080～1107）によって 始められた造営活動は 13 世紀のジャヤヴァルマンVII世の時代にま で続いていたと考えられている注16)。

回廊, 囲壁, 城壁の各辺には, 中心祠堂からの南北主軸と東西副軸 との交点に楼門が設けられているが, 城壁の東門はムン川の氾濫に よって破壊され，今はその基壇の一部が残るのみである。城壁の南門 は, 古の王道の終着点でもあり, プラトゥ・チャイ（勝利門）と呼ば れている。また北門はプラトゥ・ピー (死者の門), 西門はプラトゥ・ ヒン（石の門）と呼ばれている。

ピマーイにプラトゥ・チャイから入り暫く北進すると,左手に宝 物庫が見えてくるが, その用途や成立年代に関して詳しいことは分 かっていない。さらに北へ進むと,ナーガを象った闌干を持つテラス があり,このテラスによって現世と神々の世界であるメール山が結 ばれている。テラスは囲壁の南門に直結しており,そこにはピマーイ 寺院の建立年代に拘る碑文が刻まれている。囲壁をすぎると, 回廊と の間に小さな池を四方に配したテラスがあり,これによって囲壁と 回廊は平面構成上見事に融合していると言える。回廊と囲壁の間の 空間には, バンナライと呼ばれる経蔵が東西副軸を中心として対象 に配置されているが,これに関してもその用途や成立年代は不明で ある。屋根の落ちてしまっている回廊を抜けると,そこには 3 つの基 壇に乗った 4 つ塔が立っている。回廊の南門から見て右手は, ジャ ヤヴァルマンVII世によるとされる注17) プラーン・ブラフマダットと 呼ばれるラテライト造の塔であり,その中からは 3 体の像が発見さ れている。現在はブラフマダット像が北を向いて安置されており, この像はジャヤヴァルマンVII世を表しているという注18)。南門より 左手には, 1 つの基壇の上に南北に並ぶ 2 つの構築物が並んでいる。 北側のものからはシヴァ・リンガが見つかっており,ヒンドゥーの祠 と呼ばれているが, その用途は不明である。南側にはプラーン・ヒ ン・デンと呼ばれる塔があり, スーリヤヴァルマン II 世 (1113〜1150) によって建立されたとされている注19)。

そして回廊の中央には, プラーン (ストゥーパ) とモンドップ（講 堂), 小回廊によって構成される中心祠堂が敢えている。回廊, 囲壁, 城壁に設けられた 12 の楼門の位置を規定している主・副軸は, プラ ーンの中心で交差している。即ち, この都城の起点はプラーンの真中 心にあり, そこが正しく世界の中心であることが理解される。

中心祠堂とそれを取り囲む要素（回廊, 囲壁, 城壁）との関係に注
目すると, 興味深い事実が浮かび上がる。3つの寺院の囲壁の縦横比 は,いずれも短辺を基準として $1: 1$ 1. 25 と正方形に近い長方形で ある。しかし，ピマーイの城壁は $1: 1.84$ と長辺が 2 倍近い。ただ, 城壁の対角線は囲壁の南門の上で正確に交差しており, 寺院の軸線 により規定される起点（中心祠堂のプラーンの中央）と城壁の基点 としての囲壁南門の中央との距離の 2 倍の長さ（a）が, 軸線の基点 から城壁の東西楼門までの距離とちょうど一致する。これらのこと からは, ジャヤヴァルマンVII世はピマーイの城壁を築く際その図形 的中心を寺院の囲壁南門に求め,軸線の基点との距離を基にしてそ の規模を決定したのではないか, という推論が成り立つ。しかし、都 市計画図などこれを実証する具体的な手がかりがない以上、この推 論をさらに検証するためには、計画モデュールについて他の遺構と の比較も含めた検討が必要となる。

城壁内部にはスラ・クワン, スラ・プルン, スラ・ケーオという 3 つの溜池があり, 12 世紀当時からのものであるとされているが, こ れらの溜池は囲壁と城壁の間に整然と配置されており, 当時城壁内 に寺院の軸線に従った街路が形成されていた可能性を示している。

\section{4 ピマーイの街区構成}

ピマーイが, 寺院を中心とした居住区が城壁で囲まれた都城であ ることは確認できるが, 残念ながら建設当時の街区割りや街路構成 を示す地図や資料は残されていない。

\section{4-1 街路の変遷}

現在残っているピマーイの古地図には以下の 3 種類がある。いず れもこの 100 年の間に描かれたものであり, 19 世紀以前のピマーイ の様子を伝える地図は見つかっていない。

(1)図 5 は 1907 年にL. ラジョンキエール Lajonquiereによって描 かれたものである。この地図をみると,その街路形状は直線的で以下

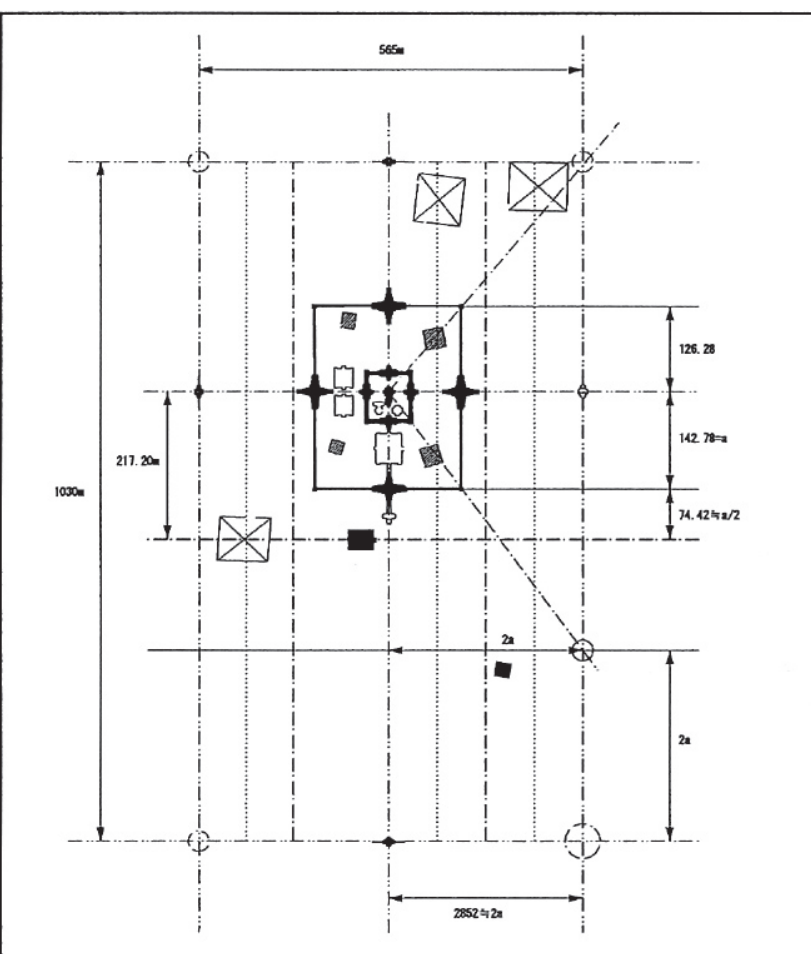

図 4 ピマーイの計画寸法 
の特徵が読み取れる。

i . 城壁内への宅地の集中：現在のピマーイにおいても, 宅地は 城壁を境に極端に減少する。住宅が連続して建て込んでいるのは東 側のみであるが,その規模は非常に小さい。北はムン川があり, 西は 環濠の跡が残る。南側はプラトゥ・チャイ周辺に芝生や池が配され 広場のようになっているが, それ以外のエリアには住居等の建物は 殆ど見られない。城壁の内部に集中的に居住していたことが窥える。

ii . 現在の道路構成との相違 : この地図からは, ピマーイ寺院の 形状が及ぼす街路構成への強い影響がうかがえる。囲壁の各辺に接 するように引かれた 4 本のタノン（大通り, 後述) は, 他の夕ノンに 比べて極端に太く強調されており, 寺院の中央祠堂を基点とした東 西南北の軸を担うタノンも城壁に設けられた門と奇麗に接続してい る。その他のタノンに関しても主要なタノンに対して平行に構成さ れており, 全体としてピマーイ寺院の空間構成に即した街路構成で あることが見て取れる。

細かな寸法の違いを挙げれば切りがないが,この地図に描かれた 道路構成には現在のものとは決定的に異なる点がある。まず, ピマー イ寺院の寸ぐ脇を走る 2 本の南北道が最南部で街区によって行き止 まっている点。次に南西の南北に長い 2 街区の形状。現在はこの 2

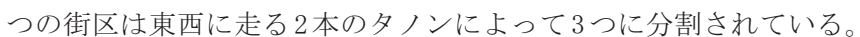

iii.ムン川による北東部の浸食：現在国立博物館のある場所は, この地図ではムン川により決壊していることがわかる。今日におい ても, 町の北東側は 3 年に 1 度程度の頻度で起こる洪水の際には最も 被害の大きな地域であるという。

iv . 街区内部の無秩序性 : 整然と格子状に並ぶタノンに比べ, 街 区の内部に走る小道には規則性が見出せず, 非常に無秩序に描かれ ている。

(2)1963 年にタイ芸術局 (fine Art Department)により作成された
ピマーイの地図には, 当時の道路構成および遺跡や池の配置が描か れている (図 7 )。現在の街区のうちいくつかは, 互いに連結した状 態でまだ大きな塊として描かれており, 先の L ラジョンキエールに よる地図が正しいと仮定するとタノンのいくつかが消滅したことに なる。また, 1963 年の地図と現在の地図を重㸚合わせると, 現在の宅 地割には 1963 年当時の道路配置の影響が見られる部分がある。

(3)上述の地図と同じ年に作成された図がある。地図というよりも 模式図で, 作成当時の街路や街区の寸法と, 特徴的な建物の配置, 土 地の使われ方などが描かれており, 作成当初, 即ちピマーイ寺院の修 復工事が終了したころのピマーイの概要を伝えてくれる。図 7 は夕 イ語で書かれたこの地図を翻訳し整理したものである。特記す心゙き 点は以下の通りである。

・北門が水門プラトゥ・ナム Pratu Nam と表記されている点

・現在国立博物館のある場所に軍事施設と区役所がある点

・ワット・ドゥムの南の土地が新区役所の予定地であった点

・要人の住居が散在している点北門は現在, プラトゥ・ピーPratu Pi (死者の門) と呼ばれているが, この時点では水門と呼ばれていた

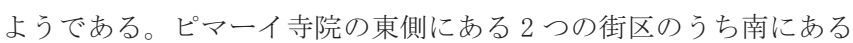
街区には, 役人が住んでいたということであるが, 調查時に恐らくそ の住居であったと考えられる住居を発見した。1911 年, ラーマ5 世 の王妃がピマーイを訪れた際, この街にあった 16 のタノンに名前を 与えたとされている。これらの古地図から明らかになった街路の変 遷をまとめたものが図 8 である。ピマーイの街路構成はその時々に よって変化しながらも, ピマーイ寺院の主軸線と副軸線を構成する 街路, およびピマーイ寺院を一周する円環型の街路は一貫して変化 を免れていることがわかる。また, 街路をその走る方角で分類すると 「寺院軸型」と「絶対方位（東西南北）型」に分けられるだろう。 寺院軸は真北から約 20 度西に傾いた状態で直行しており,この軸に

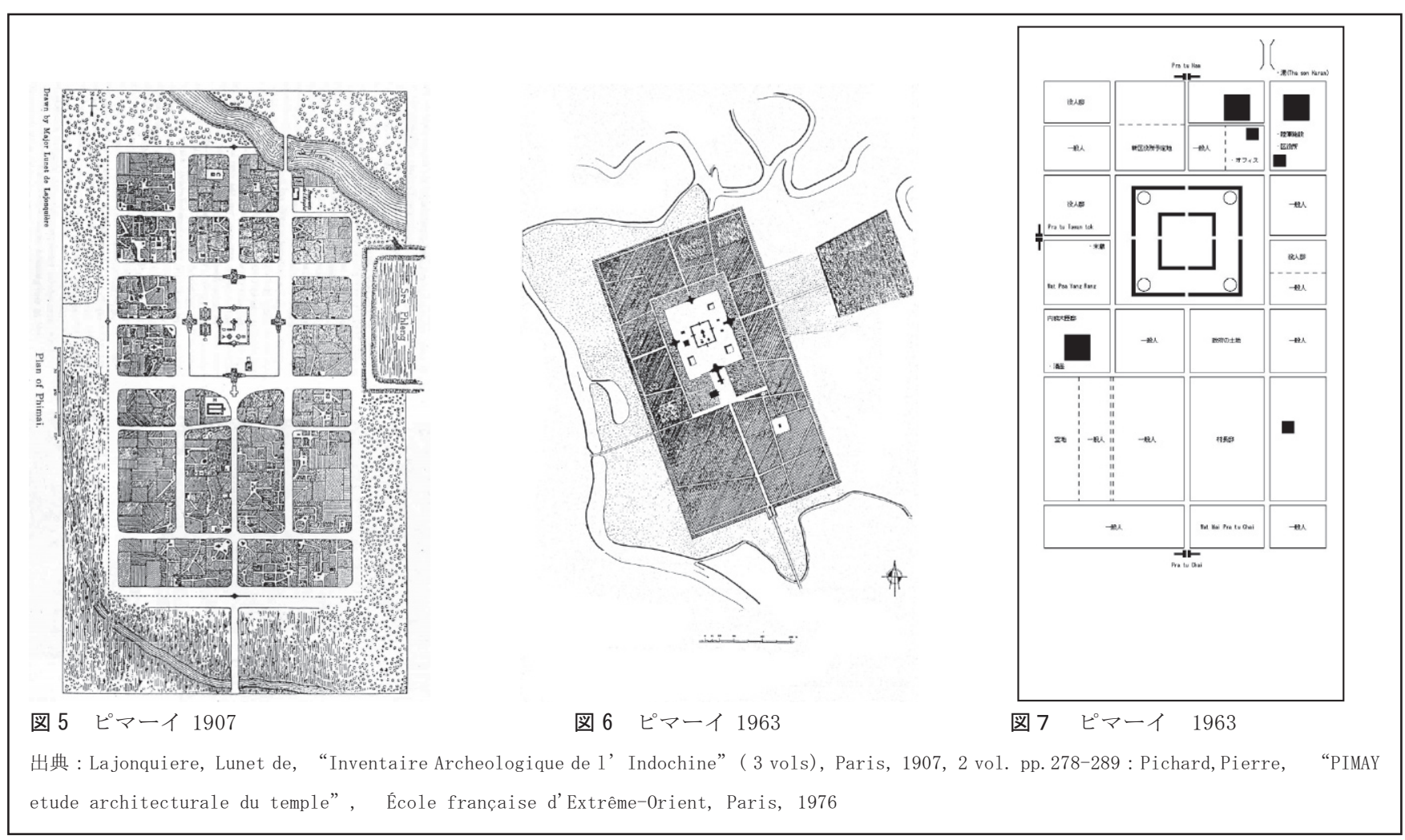


したがって形成された街路は「寺院軸」型と解釈できる。しかし古 地図においても現在の地図においても,この「寺院軸」型には当ては まらない街路がある。それらの街路はその全てが絶対方位（東西・ 南北）に沿って走っていることが分かる。

\section{4-2 街路体系}

ピマーイにおける街路は, ヒエラルキカルに構成されており, 以 下のように分類される。

i .タノン tanon：ピマーイ寺院の主軸と副軸とほぼ並行に, 直線 的に作られた道がタノンである。タノンは, いわば都市の主要道であ り幹線道路である。このタノンで囲まれたブロックを街区と呼ぶこ とにする。

ii .ソーイ soi：タノンに直接接続し, 街区内を縱横に走る道をソ 一イと呼ぶ。タノンに比べて極端に狭く, 基本的に自動車の通行はで きない。物理的には通り抜けのできるものとできないものに大別さ れるが, 生活道としての性格が強く, 一般的に通過のためにソーイを 利用することは稀である。

iii. トロック torok : 特徴は基本的にソーイと同様であるが, タノ ンには接続せずに,ソーイに接続する。

iv ．ラーンバーン ranban : 親族が集合して居住している際, その 住居間の庭に似た空間をいう。広場的な性格を有するこのラーンバ ーンは親しい人間同士が互いの承認の上に使用を認め合うことで有 機的に機能し, 各住居へのアプローチとして利用される。

$\mathrm{v}$ ，パワチャムヨム pawatyomuyom：直訳すると「仕方ない場合」 となる。街区内部に存在し, タノンやソーイ,トロックによってアク セス不能な宅地は, 周囲の宅地を所有する者のからその土地の一部 を分譲してもらい, 自らの宅地へのアプローチを確保することがあ る。近年, この孤立した宅地をめぐる争いが多発しつつある。

タノン, ソーイ, トロックは, その接続の条件に拠って分類される が, その関係を図式化したものが図 9 である。ラーンバーン, パワチ ヤムヨムは, 路地に当てられた土地の所有状況に応じて分類され, そ の違いを形状に求めることは困難であった。しかし地籍図と照合す ると, 路地と確認される場所には, 路地に相当する区割りがなされて いるものとそうでないものがあることが分かった。商業施設の密集

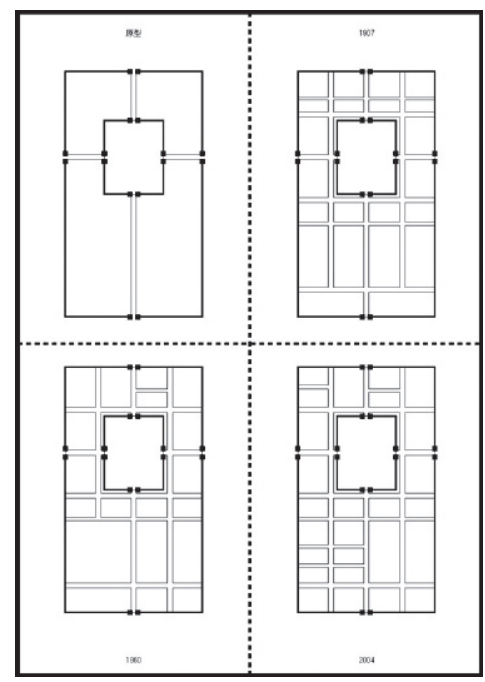

図 8 ピマーイ街路変遷図
するタラート・マイ地 区の路地の多くは前者 で,行政によって管理 されているのに対して, 北部の街区では殆どが 住民間で折り合いをつ けて路地機能を有効に している。バンコクな どの都心においては住 民の転居が激しく, 必 ずしもうまく調整がと れず,パワチャムヨム に関する条例を制定し ている。ピマーイにお いては, 今のところこ うしたインフォーマル な路地形成が続いてい
る。調查で測定したタノンの幅 員注20) とソーイの入口付近の幅 注21）を集計すると,タノンの幅 員は平均して約 $15 \mathrm{~m}$, 路地入口 の幅は平均して $3 \mathrm{~m}$ となり,タ) ンと路地は機能的にも形状的に も全く異なる。このように広い タノンの路肩の使用方法として 特に注目したいのは,タラー ト・マイ地区（図 10）における 建物と街路の間にある歩道に当 たるスペースである。現在使用

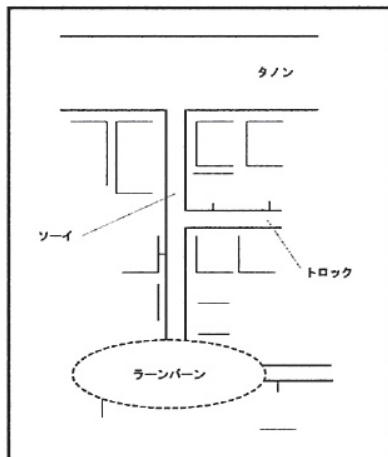

图 9 街路のヒエラルキー
されている地籍図上 (全国的には、1901 年に内務省土地局によって 作成、1985 年に航空地図をもとに修整が行われたものが用いられて いる)にはこの歩道を示す境界線は明記されておらず, 公私のどちら に含まれるのかが問題となる。地籍図は基本的に 1 つの街区ごと描 かれているが,タラート・マイの幾つかの街区に関しては 1 つのシー 卜にまとめて描かれている。道の両側にショップハウスの建ち並ぶ チョムスラーサーデット通りの北部は、明らかに南の寺院のある地 区の幅員より狭く、かつての街路の一部が宅地化されたと考えられ る。また、ショップハウスの通路が私有地を提供するものかどうか は他の都市と比較する上で興味深い。この通りの地積図上の距離と 調查によって得られた詳細な街路断面の水平方向の寸法を照合した のが表 1 である。建物間の幅を A, 歩道を除いた街路幅を B とする。

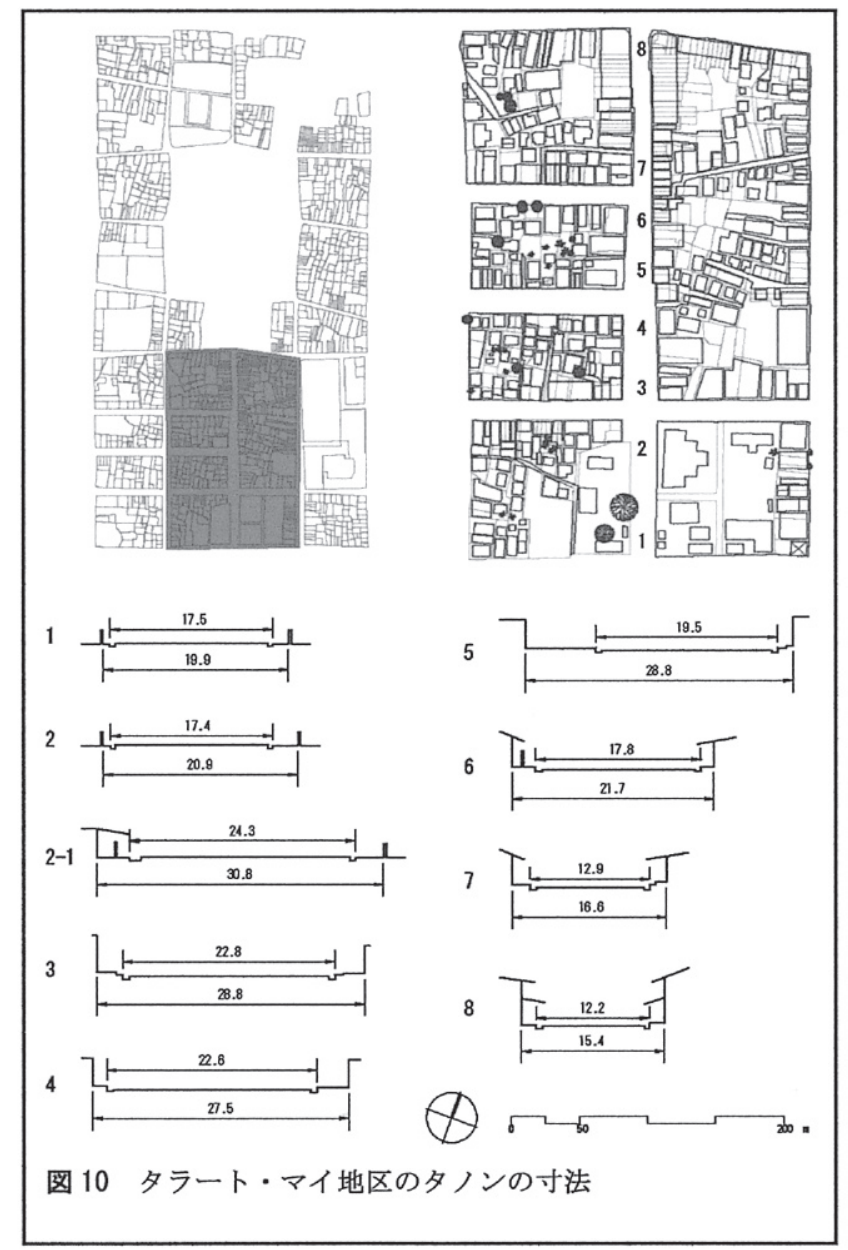


表 1 タノンの道路幅員 $1 \sim 8$ は図 9 の番号

\begin{tabular}{c|c|c|c|c|c} 
& 実測值 $\mathrm{A}$ & 差 $\mathrm{A}$ & 実測值 $\mathrm{B}$ & 差 $\mathrm{B}$ & 地積図上の宅地境界線幅 \\
\hline 8 & 15.4 & 1.63 & 12.2 & 1.57 & 13.77 \\
\hline 7 & 16.6 & 2.89 & 12.9 & 0.81 & 13.71 \\
\hline 6 & 21.7 & 3.52 & 17.8 & 0.38 & 18.18 \\
\hline 5 & 28.8 & 7.93 & 19.5 & 1.37 & 20.87 \\
\hline 3 & 27.5 & 2.71 & 22.6 & 2.19 & 24.79 \\
\hline 2 & 28.8 & 2.15 & 22.8 & 3.85 & 26.65 \\
\hline 1 & 20.9 & 1.31 & 17.4 & 2.19 & 19.59 \\
\hline
\end{tabular}

差 A（A）とは実測值 A（B）と地積図上の宅地境界幅とを比較し た際の差である注22)。この表の差 A, 差 B を見比べてみると, 実測点 1 から 3 については南側の両街区には寺院の塀があり, 道幅が変わる ことはないため, 特に大きな差はないのに対し, 実測点 4 から 8 では 宅地境界幅との差が $2 \mathrm{~m}$ 未満の数は差 Bの方が多く, 宅地境界線は実 測值 B に近いことがわかる。これより,この通りにおいて歩道は個人 所有の宅地に含まれると考えられる。ショップハウスはこの歩道部 分に差し掛けの屋根を設けており, それらが連なってアーケードの ようになっている。またこの境界線の外側, 即ち街路側には排水溝が 設けられている。

以上から、タラート・マイの南部の街路幅を狭める形で北部のシ ヨップハウス街が形成され、私有地化された上でアーケード様の通 路が形成されたと考えることができる。

\section{4ー3 宅地とアプローチ}

地籍図を基にそれぞれの宅地をそのアプローチの種類によって 分類すると図 11 のようになる。

i . タノンに向けてエントランスを持つ宅地（街路型）

ii . 路地に対してエントランスを持つ宅地（路地型）

iii. それ以外の宅地

タイプ iii は, さらに以下の 2 種類に分類可能である。親族につい ては, 悉皆調査によって, 宅地毎に親族関係を明らかにした。

iii-1. 街路型・路地型に属する宅地と一体になって 1 つの所有 者に使用されている宅地（拡張型）

iii-2. 親族の宅地を通ってアクセス可能な宅地（親族型）

それぞれの宅地をそのアクセスによって色分けしてみると, 公道 であるタノンに面さない宅地が支配的であることに驚かされる。ま た, 多くの宅地は路地に対してアクセスを持っており, ピマーイの住 環境における路地の重要性がよくわかる。また, 近年の区画整理によ り街区が細分化された街区においてはタノンに面する宅地の奥行き が小さくなることで, 路地型や拡張型, 親族型の宅地が積極的に生成 されているように見られる。街路型が卓越する街区の殆どは溜池や 寺院といった広大な非居住地を有している特殊な場合である。親族 型はピマーイ北側に位置する街区に多く見られ, 親族による繋がり が未だに強く残っていることが分かる。また, 拡張型はショップハウ スを有する街区に集中している。

すなわち, ピマーイの居住スタイルは A. 街路に面し商業を基盤と した職住一致型の居住スタイル, $\mathrm{B}$ 。街区内部において親族の繋がり を基盤とした集団居住スタイルの 2 つに分けることが出来る。

\section{まとめ}

本稿で明らかとしたことは以下の諸点である。

(1) ピマーイの街路には,タノン,ソーイ,トロックなどいくつか の種類があり,ヒエラルキカルな体系をなしている。また,限 られた資料からではあるが,街路体系の変遷について明らか にした。興味深いことは,南北から西に 20 度傾斜した主軸と それに直行する副軸で構成される街路と東西,南北に向く街 路があり,前者から後者へ変化していったと考えられること

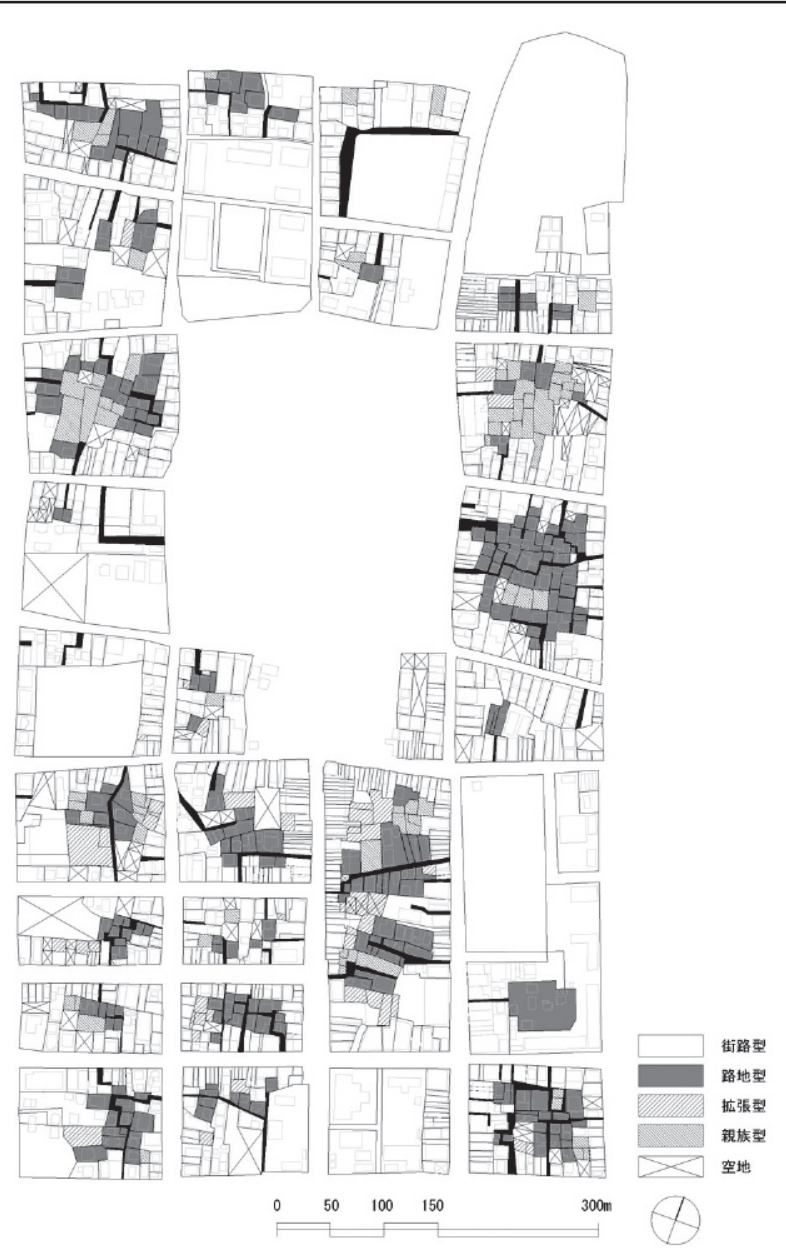

図 11 宅地へのアプローチ類型 
である。

(2) 現在の街区構成が建設当初に遡ることはない。とりわけ,ショ ップハウスの立地は近年のことである。しかし,クメールでは 一般的であったと考えられる高床式住居も見られ,手掛かり の少ないクメール都市の居住地構成を窥う事例であること を明らかにした。

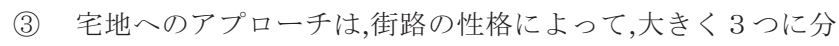
けられる。そして,街区はタノン（大通り）に接する「おもて」 と,内部の「あんこ」の部分に分けられる。

ピマーイにおける諸施設の分布, ショップハウスと高床式住居を 中心とする住居の類型については続稿としたい。

\section{参考文献}

1) Adulyapichet, Apiwan (ed) : The Aerial Views of Seven Khmer Sanctuaries Wonders of Northeastern Thailand, Sriboon Printing, 2002

2）千原大五郎：東南アジアのヒンドゥー・仏教建築, 鹿島出版会, 1982

3) Clement-Charpentier, Sophie: Permanence of Rural Settlements in Thai Towns, Dwellings, Settlements and Tradition cross-cultural perspectives, IASTE, 1989

4) 布野修司: 曼茶羅都市一ヒンドゥー都市の空間変容一, 京都大学学術出版 会, 2006

5) Higham, Charles : The Civilization of Angkor, Weidenfeld \& Nicolson, 2001

6）広岡公夫：古寺伽藍中軸線方位と考古地磁気一日本における磁石使用の 起源について一, 考古学雑誌, 考古学会, 聚精堂, 1976

7）廣富純：ピマーイ（タイ,イサーン）の都市空間構成に関する研究, 京都 大学修士論文, 2005

8）石井米雄：タイ近世史研究序説，岩波書店，1999

9）石澤良昭：古代カンボジア史研究，国書刊行会，1982

10）石澤良昭（編）：タイの寺院壁画と石造寺院，めこん，1989

11）石澤良昭(編)：東南アジア古代国家の成立と展開，岩波書店，2001

12）伊東照司：クメール古跡ピマーイ寺院一タイ国クメール遺跡調査報告 (1) 一, アジア・アフリカ言語文化研究 No. 19, 東京外語大学アジア・ア フリカ言語文化研究所, 1980

13）片桐正夫編：アンコールワットの建築学, 連合出版, 2001

14) Lajonquiere, Lunet de : Inventaire Archeologique de 1' Indochine ( 3 vols), Paris, 1907

15) Manit, Nai : Guide to Pimai and antiquities in the province of Nagara Rajasima (Khorat), The Fine Art Department, Bangkok, 1962

16）三木栄：暹羅の芸術，黒百合社，1930

17) Pichard, Pierre : PIMAY etude architecturale du temple, Ecole francaise d'Extreme-0rient, Paris, 1976

18）周達観, 和田久徳訳: 真臘風土記:アンコール期のカンボジア, 平凡社, 1989

19) Sutthiham, Thada: The Land Use and Change in Khmer Settlements in the Northeast, Toyota Foundation, 2004

\section{注}

注1）田中麻里,『タイの住まい』, 圓津喜屋.(Japanese), 2006 年 / Jiramanee, Suwit, "Vernacular Architecture in Northeastern, Thailand", $2000 /$ Nil-athi,Somchai, "Transformation of Northeastern Thai house, Kalasin Province", Silpakorn University, 1989/Varangkarat,Surat, "Vernacular House in Northeastern, Thailand”,Sakonakorn Cultural Center Print, 1989 など。

注2）タイにおけるショップハウスについては,Nawit Ongsavangchai, Shuji Funo: Consideration on Formation and Typology of Shophouse in Ratanakosin Area, Bangkok, Thailand, ラッタナコシン地区（バンコク）のショップハウ スの形成と類型に関する考察, Journal of Architecture, Planning and Environmental Engineering, Aij, no. 577, pp9-15, 2004.年 3 月など Nawit Ongsavangchai による一連の研究がある。

注3）タイ東北地方に残されたクメール時代の都市集落については,Sutthiham, Thada(2004)が写真集という形であるが概観している。ピマーイは,その中で
最も整然と残っている例である。

注4）調査者は,布野修司およびナウィット・オンサワンチャイである。

注5）調査参加者は,廣富純,ナウィット・オンサワンチャイ,布野修司,山本直 彦他。

注6) タイにおける行政組織は,州,県,郡,区からなり,その下に市街地を集中的 に管轄する役場が置かれる。

注7）テッサバーン・タンボン・ピマーイのこと。

注8）ピマーイ役場作成の地籍図より推定。

注9）伊東照司, 『クメール古跡ピマーイ寺院一タイ国クメール遺跡調查報 告 $(1)$ —』, アジア・アフリカ言語文化研究 No.19, 東京外語大学アジア・ アフリカ言語文化研究所, 1980, p.192

注10）現在ユネスコの世界文化遺産への登録を目標としているが,これら保 存修景活動を通してその指揮をとった人物が亡くなり,活動の求心力を久 いた状態のまま停滞している。

注11）一般には 1108 年に建立された晚期バプーオン建築様式のプラサート であるという。千原大五郎は『東南アジアのヒンドゥー・仏教建築』の中 でアンコール・ワット様式に分類しているが,アヌウィット・チャレンスプ クン Anuvit Charernsupkul は『タイの寺院壁画と石造寺院』の中でバプーオ ン様式後期としている。

注12）石澤良昭（編），『夕イの寺院壁画と石造寺院』,めこん, 1989,p.146 注13) 京都大学大学院理学研究科附属地磁気世界資料解析センター地球惑 星科学教授。直接の教示による。

注14） アンコール朝の第二十代国王（1130 年-1218 年,在位 1181 年 -1218 年)。アンコール・トムが建設されたのは,このジャヤヴァルマン $\mathrm{VII}$ 世の時 代で,国内の街道整備,病院の建設を積極的に行なった。

注15） ナン・スラ・ポムとは,伝説上の美女ナン・オラピンが髪を洗うとい う意味である。

注16）中心祠堂の前面西側にあるプラーン・ヒン・デンはスールヤヴァル マン II 世によって,東側にあるプラーン・ブラフマダットはジャヤヴァルマ ンVII世によって,それぞれ建立されたものであると考えられているし,城壁 の南門からはジャヤヴァルマンVII世治世において一般的であった像が数体 発見されている(伊東照司, 『クメール古跡ピマーイ寺院一タイ国クメール 遺跡調査報告 $(1)-』$, ア アジア・アフリカ言語文化研究 No.19, 東京外語 大学アジア・アフリカ言語文化研究所, 1980, p.192)

注1 7 ） Saraya,Dhida, “Travel Guide to Prasat Hin Phimai”, SEEDA PRESS, 1999, p.46

注1 8) Saraya,Dhida, “Travel Guide to Prasat Hin Phimai”, SEEDA PRESS, 1999, p. 48

注19) Saraya,Dhida, “Travel Guide to Prasat Hin Phimai”, SEEDA PRESS, 1999, p.49

注2 0) 建物間の距離を街路に垂直に $50 \mathrm{~m} の$ 巻尺で測定した。

注21）垣根などにより境界の曖昧なものは,通行可能な幅として測定した。 注22）但し,すべての実測点で宅地境界線幅は $\mathrm{AB}$ 間の空間に収まっている ため,差 A と差 B の絶対值は正負が逆になる。

(2009年 2 月 1 日原稿受理, 2009年 7 月 29日採用決定) 